\title{
Vertegenwoordiging van oude en nieuwe breuklijnen in de Lage Landen
}

\author{
Karen Celis en Bram Wauters
}

ABSTRACT: Representation of Old Cleavages and New Groups in the

This article investigates whether group-based politics is still relevant in Belgian and Dutch politics. Based on the PARTIREP MP Survey it more precisely studies the extent to which Belgian and Dutch parliamentarians in comparison to other European countries attach importance to the representation of 'old' cleavage groups (class and religious groups) or new groups (age groups, women and ethnic minorities), and which strategies are considered most appropriate. Group representation of old and new groups is found to be of great importance in both countries. Class is not dead and age groups are also highly represented. In contrast, religious groups and ethnic minorities receive far less attention in the Low Countries. Notwithstanding these similarities, there is also cross-country variation regarding the level of importance (greater in the Netherlands), the represented groups and the strategies for representation.

KEYWORDS: group representation, members of parliament, Low Countries, class, gender, ethnicity

\section{Inleiding}

Voor een groot stuk van de twintigste eeuw werd het partijpolitieke landschap in West-Europa op een uitgesproken deterministische wijze bepaald door de klassieke breuklijnen (Lipset \& Rokkan, 1967). Sterk van elkaar onderscheiden maatschappelijke groepen - sociale klassen, religieuze en regionale groepen - hadden lange tijd een duidelijke politieke vertaling onder de vorm van partijen en parlementsleden die zich uitdrukkelijk tot doel stelden de belangen van hun groep te verdedigen. Denken we maar aan socialistische partijen die de arbeidersbelangen behartigen. In de naoorlogse periode vond er evenwel een proces van ontzuiling 
plaats dat zich ook uitte in een 'ontdooiing' van het partijpolitieke landschap. Traditionele breuklijnen in de samenleving vervaagden en bijgevolg verminderde ook de relevantie van de verdediging van deze groepsbelangen. Partijen verruimden hun doelpubliek en wensten zich niet meer exclusief te verbinden met één welbepaalde maatschappelijke groep. De traditionele, groepsgebaseerde politieke vertegenwoordiging, waarbij partijen de belangen van klassieke maatschappelijke groepen verdedigen, lijkt vandaag dan ook verdwenen te zijn of het belang ervan lijkt alleszins sterk verminderd te zijn.

De vraag die dit artikel behandelt, is of samen met het verminderen van het belang van de klassieke breuklijnen alle 'groepspolitiek' uit het partijlandschap gewassen is. Met 'groepspolitiek' verwijzen we naar het fenomeen waarbij de politiek in functie wordt gesteld van de vertegenwoordiging van maatschappelijke groepen die omwille van hun specifieke kenmerken en (vaak achtergestelde) structurele positie in de samenleving politieke noden en behoeften hebben (Phillips, 1995). Welke groepen onderwerp zijn van groepspolitiek is onderhevig aan evolutie en wordt bepaald door de maatschappelijke en politieke context. Eveneens veranderlijk is de manier waarop de vertegenwoordiging van groepen gerealiseerd wordt met als belangrijkste onderscheid een strategie gericht op de fysieke aanwezigheid van de betrokken groep in de besluitvorming (descriptieve vertegenwoordiging) dan wel een strategie gericht op het kanaliseren en vertegenwoordigen van de belangen, visies, wensen en noden van die groep (substantiële vertegenwoordiging). Het doel van dit artikel is na te gaan of en in welke mate groepspolitiek belangrijk is in de hedendaagse politiek met inachtneming van verschillende groepen en strategieën.Het artikel schrijft zich zodoende in in het debat dat momenteel heerst over de mate waarin de klassieke breuklijnen nog relevant zijn om de hedendaagse politiek te vatten en de mate waarin het partijlandschap al dan niet wordt vormgegeven door nieuwe waardebreuklijnen die ook in zekere mate op maatschappelijke groepen geënt zijn (Inglehart, 1977). In de naoorlogse periode is de aandacht voor maatschappelijke groepen zoals vrouwen en etnische minderheden sterk toegenomen. Daarbij is ook heel wat aandacht besteed aan de politieke (onder)vertegenwoordiging van deze twee groepen. Omwille van de vergrijzing van de bevolking en een aantal actuele discussies zoals de verhoging van de pensioenleeftijd worden leeftijdsgroepen (zowel ouderen als jongeren) ook in toenemende mate als een politiek relevante groep beschouwd (Enyedi, 2008). Naast de vraag of groepspolitiek op basis van de oude breuklijnen nog aan de orde is, rijst dus ook de vraag of deze wordt aangevuld of vervangen door groepspolitiek op basis van nieuwe breuklijnen en groepen.

Dit artikel focust op de groepsvertegenwoordiging in twee West-Europese democratieën, België en Nederland. Deze keuze is niet toevallig. Beide landen kenden oor- 
spronkelijk een sterke verzuiling die gevolgd werd door een snelle en ingrijpende ontzuiling (Lijphart, 1968; Huyse, 1970). Deze ontzuiling ging onder meer gepaard met afnemende ledenaantallen van politieke partijen en een hoge volatiliteit van de kiezer. Het aantal wisselende kiezers en het aantal kiezers dat pas op het laatste moment besliste op wie te stemmen, nam in Nederland in de jaren 1990 opvallend toe; de binding met een bepaalde partij nam af; en de binding met Kerk en sociale klasse werd minder determinerend voor het stemgedrag (Van der Kolk, 2000a en 2000b; Irwin \& Van Holsteyn, 2002; Deschouwer \& Lucardie, 2003). Voor Vlaanderen krijgen we een soortgelijk beeld met dalende partijtrouw van de kiezers en verzuilde partijen (vooral christendemocraten en socialisten) die hun aanhang minder goed kunnen vasthouden. De ontzuiling kwam in België evenwel later en was ook minder diepgaand (Quintelier \& Hooghe, 2010). Deschouwer en Lucardie (2003, p. 152) concluderen niettemin dat de structuur zowel uit het Belgische als uit het Nederlandse partijlandschap is verdwenen: "De eens zo diep en stevig in de samenleving verankerde partijen zijn hun ankerpunten kwijt”.

Naast een gelijklopende verzuilingsgeschiedenis hebben beide landen ook expliciet beleidsaandacht voor nieuwe groepen. Ze voeren een gelijkekansen- en antidiscriminatiebeleid sinds de jaren 1980 dat in hoofdzaak gericht is op vrouwen en etnische minderheden (Celis et al., 2012). Politieke vertegenwoordiging van vrouwen en etnische minderheden staat in beide landen op de agenda. Enkel België heeft echter sinds de jaren 1990 quota voor de politieke vertegenwoordiging van mannen en vrouwen op de kieslijsten (Meier, 2000), waaruit we concluderen dat België meer dan Nederland aandacht heeft voor descriptieve vertegenwoordiging van vrouwen. In beide landen hebben niet-EU-burgers stemrecht bij lokale verkiezingen. Op dit vlak liep Nederland (invoering in 1986) voor op België (invoering in 2004). België en Nederland - beide neocorporatistische consensusdemocratieën - hebben een lange traditie van consultatie met het middenveld, inclusief vrouwenorganisaties en organisaties van etnische minderheden. Niettemin is dit in Nederland opvallend minder het geval sinds de 'Raad op Maat'-actie medio jaren 1990, die het aantal adviesraden en consultaties met het middenveld sterk terugschroefde (Outshoorn \& Oldersma, 2007). Over het algemeen kunnen we echter stellen dat zowel in België als in Nederland ruime erkenning bestaat van vrouwen en etnische minderheden als politiek relevante maatschappelijke groepen.

Dit artikel buigt zich over de relevantie van de traditionele en nieuwe breuklijnstructuren in de groepspolitiek in België en Nederland. Gezien de vele raakvlakken die op dit punt bestaan tussen Nederland en België verwachten we in eerste instantie dat de Lage Landen zich op een gelijkaardige wijze onderscheiden van de andere Europese landen die grosso modo een minder sterke verzuiling hebben gekend. We verwachten dus dat er weinig verschillen zullen zijn tussen Nederland 
en België. Indien er toch verschillen tussen beide landen zijn, verwachten we dat, gezien de latere en minder verregaande ontzuiling, er in België meer belang gehecht wordt aan de klassieke groepen. Inzake de nieuwe groepen is het enige verschil dat we bij Belgische parlementsleden een grotere interesse verwachten voor de descriptieve vertegenwoordiging van vrouwen als gevolg van de lange traditie inzake het gebruik van genderquota.

Na een sectie waarin de literatuur over oude en nieuwe breuklijnen en de aandacht voor groepen als vrouwen en etnische minderheden kort besproken wordt, behandelt het artikel de mate waarin Belgische en Nederlandse parlementsleden belang hechten aan de politieke vertegenwoordiging van oude maatschappelijke groepen (klasse- en religieuze groepen) en nieuwe maatschappelijke groepen (leeftijdsgroepen, vrouwen en etnische minderheden) en dit in vergelijking met andere Europese landen. We behandelen de vraag of daarbij de strategie van descriptieve of van substantiële vertegenwoordiging het meest wenselijk geacht wordt.

\section{Groepsvertegenwoordiging op basis van oude en nieuwe breuklijnen}

Deze sectie overloopt kort de literatuur inzake breuklijnen en groepsvertegenwoordiging. Deze literatuur leert enerzijds dat te verwachten is dat groepspolitiek niet langer aan de orde is, aangezien de oude breuklijnen niet meer relevant zijn. Anderzijds is groepsvertegenwoordiging toch nog steeds te verwachten om drie redenen. Ten eerste zou de vertegenwoordiging van de groepen op basis van de traditionele breuklijnen niet volledig verdwenen zijn. Ten tweede wordt gesuggereerd dat de nieuwe waardebreuklijn ook groepsvertegenwoordiging met zich meebrengt. Ten slotte bracht de vraag naar politieke gelijkheid en erkenning groepen als vrouwen en allochtonen op de voorgrond.

\subsection{De ondergang van de oude breuklijnen?}

Het partijlandschap was tijdens een groot deel van de twintigste eeuw geënt op de klassieke breuklijnen, zoals beschreven in het baanbrekend werk van Seymour Martin Lipset en Stein Rokkan uit 1967: Kerk versus Staat; Arbeid versus Kapitaal; Centrum versus Periferie; Stad versus Platteland. Breuklijnen verwijzen naar een stabiele link tussen sociale structuren (maatschappelijke groepen en hun belangen) en politieke partijen die coherentie en politieke uitdrukking geven aan de belangen, waarden en overtuigingen van die maatschappelijke groepen. Breuklij- 
nen impliceren een sterke en stabiele fusie van partijaffiliatie en groepsidentiteit (Bartolini, 2005; Bartolini \& Mair, 1990; Knutsen \& Scarbrough, 1995). In een politiek landschap bepaald door breuklijnen vallen identiteiten, ideologie en politieke actie netjes samen.

Vandaag zou een dergelijke groepspolitiek waarbij politieke partijen de spreekbuis zijn van vaste groepen in de samenleving - met, bijvoorbeeld, socialistische partijen die arbeiders vertegenwoordigen - niet langer aan de orde zijn (Dalton et al., 1984; Franklin et al., 1992). De oorzaken van het verwateren van de traditionele breuklijnen in heel wat postindustriële samenlevingen - de ontzuiling - zijn veelvuldig. De toename van de tertialisering van de arbeidsmarkt verkleinde de arbeidersklasse. De afhankelijkheid van de organisaties van de eigen zuil voor informatie, vorming, bijstand, diensten en geborgenheid verminderde verder door de mediatisering van de maatschappij, de stijgende welvaart en de ontwikkeling van de welvaartstaat, de cognitieve mobilisatie, de individualisering en de secularisatie (Enyedi, 2008, p. 289). Deze fenomenen verminderden de sociale geslotenheid en het disciplinerend vermogen van de maatschappelijke structuren en losten ze uiteindelijk ook op. In de loop van de tweede helft van de twintigste eeuw stapten burgersmeer en meer uit de gesloten en homogene socio-economische zuilen en gingen zij zelf op een meer individuele basis politieke keuzes maken.

Het oplossen van de klassieke breuklijnen en het loskoppelen van maatschappelijke groepen van politieke partijen hadden verregaande implicaties voor het stemgedrag in West-Europa (Van der Burg, 2010). Dat stemgedrag werd volatiel en deinde mee op het eb en vloed van de politieke thema's van het moment, van de populariteit van individuele politici en van de retrospectieve evaluatie van bestuurders (Enyedi, 2008; Enyedi \& Deegan-Krause, 2010). Dit luidde volgens een aantal wetenschappers onder meer het einde in van het stemgedrag volgens klasse (Clark \& Lipse, 1991). Tegelijkertijd gingen politieke partijen zich niet langer exclusief richten op traditionele maatschappelijke groepen als arbeiders en gingen ze over op een 'catch all'-strategie (Katz \& Mair, 1995; Kirchheimer, 1966; Przeworski \& Sprague, 1988). Partijen losten dus ook zelf hun maatschappelijke ankers (Enyedi, 2008).

Een aantal politicologen nuanceren evenwel het verlies aan relevantie van de traditionele breuklijnen evenals het structuurloze, flexibele en geïndividualiseerde stemgedrag. Zo wijzen Enyedi (2008) en Kriesi (2010) erop dat een aantal aspecten van de klassieke groepsgebaseerde politiek nog steeds aan de orde zijn.

Ten eerste is er de vaststelling dat, niettegenstaande arbeiders in toenemende mate voor extreemrechtse en populistische partijen stemmen en linkse partijen meer en meer stemmen halen bij de middenklasse, lang niet alle klassenpatronen uit 
het stemgedrag zijn verdwenen. Klassenverschillen doen er nog steeds toe: wanneer het beleidsvoorkeuren van kiezers betreft inzake socio-economische thema's (bijvoorbeeld de rol van vakbonden en de organisatie van de sociale zekerheid) nemen arbeiders nog steeds 'linkse' standpunten in. Klassenverschillen zijn ook zeer sturend in opvattingen inzake socioculturele en links-libertaire thema's (zoals attitudes ten aanzien van etnische minderheden). Inzake deze thema's nemen arbeiders overduidelijk een meer autoritaire positie in die hen naar (extreem)rechtse partijen leidt (Van der Waal et al., 2007). Ook Tóka en Gosselin (2010) en van der Brug (2010) wijzen erop dat electorale verbindingen tussen maatschappelijke groepen en politieke partijen nog steeds bestaan, niettegenstaande de ontzuiling. De kiezers met stabiele partijvoorkeuren en -affiliaties maken evenwel een steeds kleinere groep uit van de samenleving. Het stemgedrag volgens de klassieke breuklijnenstructuur is bijvoorbeeld nog steeds sterk in de oudere leeftijdscategorieën, maar neemt logischerwijze in toenemende mate af.

De ontzuilingsthese lijdt, ten tweede, aan een aantal problemen inzake conceptualisering. Ze staat of valt met het gebruik van categorieën en criteria die niet langer accuraat zijn in het vatten van de hedendaagse maatschappij. Het formele statuut van arbeider is misschien niet langer determinerend voor stemgedrag, maar wanneer de sociale status bepaald wordt aan de hand van andere factoren zoals werknemer-werkgeververhouding, werkomgeving, opdrachtstructuur, jobautonomie, lifestyle, consumptiepatronen en mobiliteit inzake residentie, dan tonen studies aan dat die wel zeker het stemgedrag structureren (Evans, 1999; Oesch, 2008). Bovendien bepalen andere klassieke breuklijnen gebaseerd op religie, territorium en etniciteit nog steeds het stemgedrag in grote delen van Europa (Enyedi, 2008).

Het feit dat de machtsverhoudingen niet langer bepaald worden door de klassieke breuklijnenstructuur zou bovendien niet volledig verklaard worden door het verdwijnen ervan in de samenleving. Ook een falen van het politieke systeem om dit electoraal te vatten zou dit deels verklaren. Sommige politicologen stellen dat het gebrek aan doorwerking van de klassieke breuklijnen terug te brengen is op een selectieve uitval in electorale participatie. Zo zou de vermindering in impact van klasse ook toe te schrijven zijn aan het feit dat immigranten de neiging hebben om niet te stemmen (Enyedi, 2008). Klasse is voor deze groep wel degelijk belangrijk, maar dit belang wordt slechts gebrekkig electoraal vertaald.

\subsection{Een nieuwe breuklijn?}

Naast het debat of de oude breuklijnen nog relevant zijn in het hedendaagse politieke landschap, is er het debat over een nieuwe breuklijn veroorzaakt door diver- 
gerende waardeoriëntaties. Deze breuklijn kent vele benamingen, onder andere: 'authoritarian/libertarian' (Dolezal, 2010; Flanagan, 1987; Kitschelt, 1994); 'libertarian-universalistic/traditionalist-communitarian' (Bornschier, 2010); materialist/ post-materialist (Inglehart, 1977); 'self-expression/survival' (Inglehart \& Baker, 2000). Los van de benaming en de centrale as van de breuklijn is er vooral onenigheid over het antwoord op de vraag of dit waarlijk een breuklijn betreft die aan de vereiste definitie voldoet inzake duidelijk afgebakende en stabiele maatschappelijke structuren. Om het als een breuklijn te beschouwen dient het concept 'breuklijn’ enigszins verruimd te worden, zodat het, zoals Kriesi (2010) en Enyedi (2008) suggereren, groepspecifieke partijoriëntatie, -actie en -polarisatie omsluit los van het feit of die veroorzaakt worden door maatschappelijke categorieën of waarden.

De waarden die bepalend zijn voor de nieuwe breuklijn zijn inderdaad niet exclusief terug te brengen op specifieke maatschappelijke groepen. Niettemin zijn deze waarden sterk geworteld in maatschappelijke groepen bepaald door klasse, beroep, opleiding, generatie en nationaliteit (Bovens \& Wille, 2011; Kriesi, 2010; Stubager, 2009). Met waardegebonden thema's als gelijkheid, diversiteit en tolerantie spreken politieke partijen doelgericht groepen als vrouwen en etnische minderheden aan en, vice versa, deze groepen zijn gevoeliger voor dergelijke thema's omdat zij er, gezien hun achtergestelde maatschappelijke positie, rechtstreeks baat bij hebben. Met andere woorden, ook de nieuwe waardebreuklijn vertaalt zich in groepsspecifieke politieke actie, zowel inzake (electorale)mobilisatie door politieke partijen als inzake stemgedrag.

Het is duidelijk dat de groepen die zich van elkaar onderscheiden op basis van waardeoriëntatie niet de geslotenheid, sociale controle en disciplinering kennen van de klassieke zuilen. Niettemin laten de sterk gediversifieerde nieuwe media een hoge mate van exclusieve oriëntatie op de eigen groep toe, volgens Blumler en Kavanagh (1999) zijn dit de 'electronic equivalents of gated communities'. De hedendaagse media voeden de groepsspecifieke politiek ook op een andere wijze: politieke partijen kunnen hun strategieën afstemmen op specifieke groepen waarvan ze meer gedetailleerde kennis hebben dan ooit tevoren (Enyedi 2008: 297). Dit laat toe dat er simultaan breuklijngeoriënteerde strategieën gehanteerd worden die zich richten op specifieke groepen en daarnaast catch all-strategieën gericht op de centrumkiezer.

\subsection{Een andere invulling van de groepspolitiek: erkenning van identiteit}

De klassieke breuklijnen zouden dus verwaterd zijn en vooral de vertegenwoordiging van religieuze groepen en klasse zou in belang afgenomen zijn. Tegelijkertijd 
zouden andere groepen aan belang gewonnen hebben. Gender is bepalend in de hedendaagse politiek (Inglehart \& Norris, 2000) en leeftijdsgroepen (gepensioneerden versus arbeidsactieven) kunnen dat in de toekomst ook in zeer grote mate worden (Enyedi, 2008). Vooral de ondervertegenwoordiging van vrouwen en van etnische groepen werd in de loop van de tweede helft van de twintigste eeuw geproblematiseerd (Phillips, 1995) en er werden acties ondernomen om hun numerieke vertegenwoordiging te verhogen. De aandacht voor deze nieuwe groepen en de verschuiving van de aandacht van klasse en religie naar gender en etniciteit gingen evenwel hand in hand met een nieuwe invulling van het concept gelijkheid.

Nancy Fraser (1997) en Anne Phillips (1999) stellen een verschuiving vast van economisch egalitarisme naar politieke gelijkheid. De oude benadering van gelijkheid als herverdeling met een focus op klasse moest baan ruimen voor een politiek van erkenning van identiteit met een focus op vrouwen en etnische minderheden. Vandaag wordt gelijkheid voornamelijk beschouwd als een politieke en culturele kwestie die te maken heeft met de erkenning van verschil en identiteiten gebaseerd op etniciteit en gender. De nieuwe invulling van het concept 'gelijkheid' als een politieke erkenning van verschil is radicaal anders dan de economische invulling van het concept, die veeleer tot doel had om verschillen (in casu klassenverschillen) uit te wissen. Identiteitspolitiek stelt inderdaad dat, om gelijkheid voor vrouwen en etnische minderheidsgroepen te kunnen realiseren, de verschillende posities die ze innemen in de samenleving erkend dienen te worden en in rekening moeten worden gebracht opdat ze de facto gelijkheid niet onmogelijk maken. Het miskennen van verschillen en, integendeel, het vasthouden aan een soort neutraliteit inzake gender en etniciteit, aldus Phillips, komt er in de praktijk op neer dat vrouwen en etnische minderheden zich dienen te conformeren aan normen en instellingen die noch door hen noch voor hen ontwikkeld werden. De uitkomst is dan ongelijkheid. Gelijkheid kan enkel via de erkenning van verschillen bereikt worden (Phillips, 1999, p. 25).

Deze identiteitspolitiek had haar uitwerking in aandacht voor de descriptieve en substantiële vertegenwoordiging van groepen. Descriptieve vertegenwoordiging werd gerealiseerd via de inclusie van vrouwen, etnische minderheden, maar ook van arbeiders en leeftijdsgroepen op de kieslijsten en in verkozen assemblees (voor etnische minderheden, zie. Bird, 2004; voor vrouwen, zie Krook, 2009; Meier, 2000; voor arbeiders, zie Wauters, 2012). De aanwezigheid van deze groepen betekende een belangrijke erkenning van de desbetreffende groep en van zijn belangen. De erkenning van de groepsbelangen en de politieke vertegenwoordiging ervan werd ook gerealiseerd via het aanhalen van de banden met middenveldorganisaties (onder meer vrouwenorganisaties en organisaties van etnische minderheden) (Celis, Eelbode \& Wauters, 2011). 


\section{Methodologie}

\subsection{De PartiRep MP-Survey}

Dit artikel is gebaseerd op de enquête onder parlementsleden (MP-Survey) georganiseerd door PartiRep. PartiRep is een Interuniversitaire Attractiepool gefinancierd door het Belgisch Federaal Wetenschapsbeleid die focust op participatie (Participation) en vertegenwoordiging (Representation) (www.partirep.eu). PartiRep behelst een samenwerking tussen vijf universiteiten in België en Nederland: Vrije Universiteit Brussel, Université Libre de Bruxelles, Universiteit Antwerpen, KULeuven en Universiteit Leiden.

Deze internationale MP-survey bij parlementsleden is uniek in zijn omvang: er zijn in totaal data verzameld in 15 Europese landen en in meer dan 70 nationale en regionale parlementen. Alle leden van de geselecteerde parlementen werden gecontacteerd tussen maart 2009 en januari 2011. De landen die betrokken zijn in dit onderzoek zijn Oostenrijk, België, Duitsland, Frankrijk, Hongarije, Ierland, Israël, Italië, Nederland, Noorwegen, Polen, Portugal, Spanje, het Verenigd Koninkrijk en Zwitserland. Deze landen vertegenwoordigen een grote variatie aan politieke systemen: zowel unitaire als federale staten, zowel staten waarvan de bevoegdheden al sinds jaar en dag gedecentraliseerd zijn als staten waarvoor dit proces nog maar net gestart is. Voor sommige landen (waaronder België en Zwitserland) werden alle regionale parlementen in de steekproef opgenomen; voor andere (meestal grotere) landen (zoals Duitsland, Spanje en Italië) werd op dat vlak een selectie gemaakt.

We geven nog mee dat de gebruikte methode kon verschillen van land tot land, aangezien de internationale partners zelf best konden inschatten welke methode op basis van ervaringen uit het verleden de meest succesvolle zou zijn. Zo werden zowel face-to-face-interviews als online-enquêtes gebruikt.

\subsection{Respons en weging}

Globaal werd een responsgraad van $23 \%$ bereikt. Uit die grote dataset lichten we met het oog op dit artikel de Belgische en Nederlandse parlementsleden. De Belgische parlementsleden zijn in totaal met 163 (zowel federale als regionale parlementsleden), wat neerkomt op een responsgraad van $35 \%$. De Nederlandse parlementsleden zijn enkel actief op nationaal niveau en zij zijn in totaal met 65, wat een hogere responsgraad van $43 \%$ betekent. 
De data werden gewogen volgens de partijsterkte in ieder parlement (zie appendix) en voor de gegevens voor alle landen werd een correctiefactor voor de oververtegenwoordiging van de Zwitserse regionale parlementen gebruikt. De verdeling volgens partij in onze steekproef laat geen eenduidig beeld zien: naargelang van de assemblee waarover het gaat (federaal of regionaal), is een partij de ene keer oververtegenwoordigd en de andere keer ondervertegenwoordigd. Voor Nederland zijn de parlementsleden van SP en GroenLinks wat ondervertegenwoordigd in de steekproef.

\subsection{Groepen en dimensies van vertegenwoordiging}

Voor de analyse werden twee groepen geselecteerd die centraal stonden in de 'oude' breuklijnenpolitiek in beide landen, ${ }^{1}$ met name sociale klasse ${ }^{2}$ en religie. Daarnaast betrekken we twee nieuwe groepen waarvan de vertegenwoordiging reeds gedurende een aantal decennia op de politieke agenda staat, onder meer door toedoen van middenveldorganisaties, met name vrouwen en etnische minderheden. Ten slotte selecteerden we leeftijd als een derde maatschappelijke verdeling waarvoor politieke vertegenwoordiging actueel is. ${ }^{3}$

Om de vertegenwoordigingsstrategieën van parlementsleden te vatten, werden in de vragenlijst zowel vragen opgenomen over hun attitudes als over hun feitelijke gedrag. Dit onderscheid is belangrijk, aangezien onderzoek heeft aangetoond dat parlementsleden die zich bewust zijn van de problemen van een bepaalde sociale groep en daar ook belang aan hechten, er niet steeds in slagen om deze attitudes ook om te zetten in gedrag, onder meer omwille van partijdiscipline (bv.Celis \& Wauters, 2010; Cowley \& Childs, 2003).

De eerste vraag over attitude peilde bij de parlementsleden hoe belangrijk het voor hen persoonlijk is om de zienswijzen en belangen van diverse maatschappelijke groepen te promoten. Een tweede vraag peilde naar de attitude ten opzichte van een evenwichtige descriptieve vertegenwoordiging van een specifieke groep in het parlement. Een derde vraag heeft betrekking op contacten met middenveldorganisaties. Deze vraag heeft niet langer betrekking op attitudes maar op gedrag. Er werd gevraagd hoe dikwijls parlementsleden in het afgelopen jaar contact hadden gehad met organisaties die opkomen voor de belangen van specifieke achtergestelde groepen. Merk op dat we dus niet de de facto descriptieve of substantiële vertegenwoordiging van de betrokken groepen bevragen maar wel of de parlementsleden descriptieve vertegenwoordiging belangrijk achten en/of strategieën hanteren om ervoor te zorgen dat groepsbelangen kunnen doorstromen naar de besluitvormingsagenda. 


\section{Empirische resultaten}

De bespreking van de empirische resultaten is opgedeeld in drie delen. Eerst geven we weer in welke mate Belgische en Nederlandse parlementsleden het belangrijk vinden om groepsbelangen te vertegenwoordigen en dit in vergelijking met andere Europese landen. Nadat we dit algemeen beeld geschetst hebben, gaan we dieper in op de verschillende groepen apart, waarbij we zowel aandacht besteden aan de 'oude' groepen als aan de 'nieuwe' groepen. Tot slot verleggen we de focus van attitude naar gedrag en gaan we na op welke wijze parlementsleden uit de Lage Landen die specifieke groepen willen vertegenwoordigen: zetten ze vooral in op contacten met relevante organisaties of verwachten ze toch meer heil van de aanwezigheid van parlementsleden uit de desbetreffende groepen in het parlement?

\subsection{Algemeen beeld}

De ondervraagde parlementsleden konden op een schaal van 1 tot 7 aanduiden in welke mate ze het persoonlijk belangrijk vonden om belangen van specifieke maatschappelijke groepen te vertegenwoordigen (zie tabel 1). De Belgische parlementsleden halen gemiddeld een score van 4,38 als het gaat over de wil om belangen van specifieke maatschappelijke groepen te verdedigen. Dat is eerder aan de lage kant, en ligt onder het gemiddelde van 4,60 voor parlementsleden uit de andere landen waarin dit onderzoek gevoerd is. Nederlandse parlementsleden, daarentegen, halen met 5,20 een veel hogere gemiddelde score. Nederlandse parlementsleden scoorden ook in eerdere internationale onderzoeken (Thomassen \& Esaiasson, 2006) al erg hoog inzake het belang dat wordt gehecht aan groepsvertegenwoordiging. Belgische en Nederlandse parlementsleden verschillen significant van elkaar en Nederland scoort ook significant hoger dan de andere landen uit dit onderzoek.

TABEL 1. Score op de vraag in welke mate men het persoonlijk belangrijk vindt om inzichten en belangen van groepen in de samenleving te vertegenwoordigen (schaal van 1 tot 7$)$.

\begin{tabular}{lcccc}
\hline Land & N & Gemiddelde & Std. Deviatie & $\begin{array}{c}\text { \% respondenten in } \\
\text { categorieën 5-6-7 }\end{array}$ \\
\hline België & 157 & 4,38 aа & 1,424 & $47,8 \%$ \\
\hline Nederland & 43 & 5,20 aа & 1,631 & $69,8 \%$ \\
\hline Alle andere landen uit het onderzoek & 1529 & 4,60 & 1,71 & $54,3 \%$ \\
\hline
\end{tabular}

Anova: $F(2,1725)=4,047 ; p<0,05$; varianties zijn niet gelijk;

Tamhane-test:

a $p<0,1$; aa $p<0,05$; aaa $p<0,01$ significant verschillend met België/Nederland

${ }^{\circ} \mathrm{p}<0,1 ;{ }^{\circ 0} \mathrm{p}<0,05 ;{ }^{\circ 00} \mathrm{p}<0,01$ significant verschillend van de andere landen uit het onderzoek 
Ook als bekeken wordt hoeveel parlementsleden zich bevinden onder degenen die veel belang hechten aan groepsvertegenwoordiging (score van 5, 6 of 7 op de 7-puntenschaal) komt hetzelfde beeld naar voren: Nederland scoort veel hoger dan België en veel hoger dan gemiddeld op dat vlak. Van de Belgische parlementsleden hecht minder dan de helft veel belang aan groepsvertegenwoordiging. Daarmee scoren de Belgische parlementsleden lager dan het gemiddelde in de andere Europese landen. Deze verschillen zijn statistisch significant (chi $\left.{ }^{2}=6,803 ; p<0,05\right)$.

We dienen hierbij aan te stippen dat het aantal Nederlandse respondenten dat op deze vraag geen antwoord gaf behoorlijk hoog was ( $\mathrm{N}=15$, of ongeveer $25 \%$ ). Het is ons niet meteen duidelijk waaraan dit ligt en of dit een invloed kan gehad hebben op de score op deze variabele.

\subsection{Welke groepen worden vertegenwoordigd?}

In een tweede fase gaan we na welke groepen de parlementsleden uit België en Nederland nu precies willen vertegenwoordigen, en of er op dat vlak verschillen zijn met de andere landen uit dit onderzoek. Meer bepaald krijgen we zo een zicht op de kwestie of de historische verzuiling in België en Nederland en de recente beleidsaandacht voor nieuwe maatschappelijke groepen hun sporen nalaten in de vertegenwoordigingsvoorkeuren van parlementsleden in deze twee landen.

Een eerste vaststelling die gemaakt kan worden op basis van tabel 2 is dat voor alle onderzochte groepen de score van de Belgische en Nederlandse parlementsleden significant lager ligt dan het gemiddelde in de andere onderzochte landen (met uitzondering voor Nederland van etnische minderheden en religieuze groepen). Voor België stemt dit overeen met het algemene beeld zoals geschetst in de vorige paragraa; voor Nederland is dit toch opmerkelijker.

De verschillen tussen Nederlandse en Belgische parlementsleden zijn verder niet zo erg groot: over het algemeen halen Belgen een iets hogere score bij de verschillende groepen en niet, zoals onze hypothese suggereerde, enkel bij de oude groepen. De verschillen in het gemiddelde zijn echter niet echt uitgesproken en nooit statistisch significant. De meest opgemerkte verschillen tussen beide landen doen zich voor bij religieuze groepen en etnische minderheden (in het voordeel van Nederland), waar Nederland niet significant verschilt van de andere landen uit het onderzoek en België wel. Ook zijn er onderlinge verschillen - zij het in iets mindere mate - inzake werkgevers en vrouwen (in het voordeel van België), al verschillen zowel België als Nederland daar wel significant van de andere landen. 
VERTEGENWOORDIGING VAN OUDE EN NIEUWE BREUKLIJNEN IN DE LAGE LANDEN
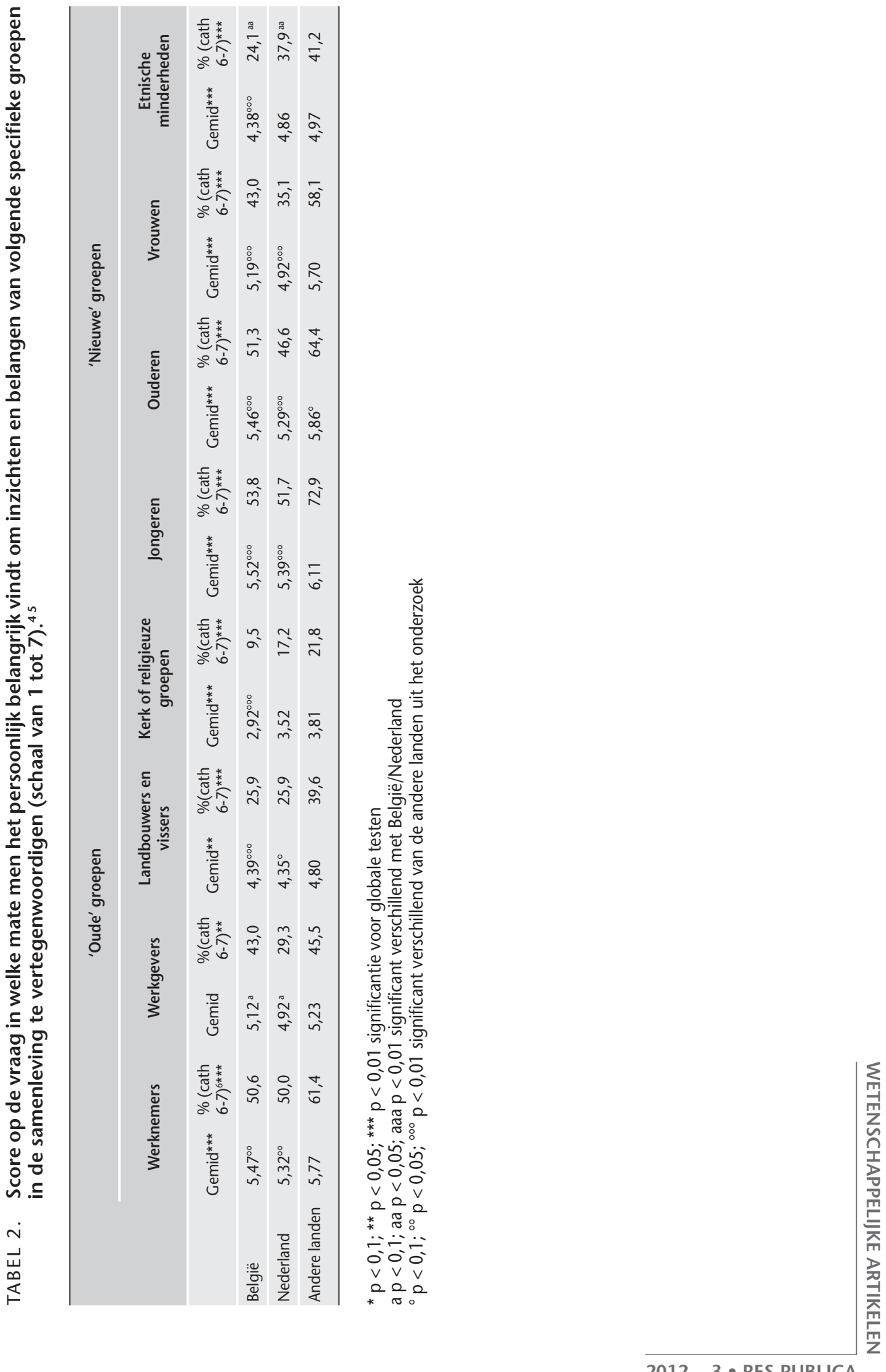
Als gekeken wordt naar het percentage parlementsleden die het vertegenwoordigen van een bepaalde groep belangrijk vinden, dan zijn er tussen België en Nederland wel (beperkte) significante verschillen inzake etnische minderheden en werkgevers.

Als we de vergelijking maken tussen 'oude' en 'nieuwe' groepen, dan komt naar voor dat beide soorten groepen voor parlementsleden uit de Lage Landen belangrijk zijn. Jongeren en ouderen (nieuwe groepen) en werknemers (oude groep) behalen zowel in België als in Nederland de hoogste scores, terwijl landbouwers en vissers (oude groep), religieuze groepen (oude groep) en etnische minderheden (nieuwe groep) de laagste score behalen. Het gaat dus niet op om te stellen dat een nieuwe groep sowieso veel aandacht krijgt van parlementsleden en een oude groep niet. In België is de gemiddelde score van erg diverse groepen als landbouwers en vissers enerzijds en etnische minderheden anderzijds trouwens nagenoeg exact gelijk $(4,39$ tegenover 4,38$)$. Tot slot scoren alle groepen (met uitzondering van de religieuze groepen) allemaal beter dan de middenwaarde 4, wat aangeeft dat parlementsleden gemiddeld genomen wel enige aandacht willen besteden aan de belangenverdediging van oude én nieuwe groepen.

\subsection{Wijze van vertegenwoordiging}

De voorgaande twee paragrafen behandelden de attitudes van parlementsleden: in welke mate zij het belangrijk vinden om maatschappelijke groepen te vertegenwoordigen. Nu onderzoeken we verder op hoe die groepsvertegenwoordiging in de praktijk best kan gerealiseerd worden: via nauwe contacten met organisaties die opkomen voor de belangen van maatschappelijke groepen of door de aanwezigheid van descriptieve vertegenwoordigers uit de desbetreffende maatschappelijke groep in het parlement.

TABEL 3. Percentage parlementsleden dat minstens $1 \times$ per maand contact heeft met relevante organisaties van die maatschappelijke groep. ${ }^{7}$

\begin{tabular}{|c|c|c|c|c|c|c|c|c|c|}
\hline & \multicolumn{4}{|c|}{ 'oude groepen' } & \multicolumn{4}{|c|}{ 'nieuwe groepen' } & \multirow[b]{2}{*}{$\begin{array}{c}\text { Gemid- } \\
\text { delde }\end{array}$} \\
\hline & $\begin{array}{c}\text { Organisaties } \\
\text { van werk- } \\
\text { nemers en } \\
\text { vakbonden }\end{array}$ & $\begin{array}{l}\text { Werkge- } \\
\text { vers-orga- } \\
\text { nisaties*** }\end{array}$ & $\begin{array}{l}\text { Land- } \\
\text { bouw- } \\
\text { organisa- } \\
\text { ties*** }\end{array}$ & $\begin{array}{l}\text { Kerken of } \\
\text { religieuze } \\
\text { organisa- } \\
\text { ties*** }\end{array}$ & $\begin{array}{l}\text { Jongeren- } \\
\text { organisa- } \\
\text { ties*** }^{* *}\end{array}$ & $\begin{array}{l}\text { Ouderen- } \\
\text { organisa- } \\
\text { ties** }\end{array}$ & $\begin{array}{l}\text { Vrouwen- } \\
\text { organisa- } \\
\text { ties** }^{* *}\end{array}$ & $\begin{array}{l}\text { Organisaties } \\
\text { van etnische } \\
\text { minderheden }\end{array}$ & \\
\hline België & $36,0 \%$ & $22,5 \%$ aаa & $10,6 \%$ & $7,5 \%$ & $28,8 \%$ aаa & $30,4 \%$ & $17,5 \%$ & $13,8 \%$ & $20,89 \%$ \\
\hline Nederland & $41,4 \%$ & $44,8 \%{ }^{\text {aaa }}$ & $18,6 \%$ & $10,2 \%$ & $49,2 \%$ aаa & $31,0 \%$ & $18,6 \%$ & $18,6 \%$ & $29,05 \%$ \\
\hline $\begin{array}{l}\text { Andere } \\
\text { landen }\end{array}$ & $40,4 \%$ & $29,2 \%$ & $20,8 \%$ & $20,0 \%$ & $46,0 \%$ & $41,3 \%$ & $27,2 \%$ & $14,4 \%$ & $29,09 \%$ \\
\hline
\end{tabular}

${ }^{*} \mathrm{p}<0,1 ;{ }^{* *} \mathrm{p}<0,05 ;{ }^{* * *} \mathrm{p}<0,01$ significantie voor globale testen

a $p<0,1$; aa $p<0,05$; aaa $p<0,01$ significant verschillend met België/Nederland 
We starten met een analyse van de contacten die parlementsleden hebben met relevante organisaties. Nederlandse parlementsleden hebben vaker contact met maatschappelijke organisaties dan Belgische. Het gemiddelde percentage parlementsleden dat minstens eens per maand contact heeft, bedraagt in Nederland $29 \%$ terwijl dit in België maar 20\% is. Nederland ligt daarmee op het gemiddelde voor de landen uit dit onderzoek; België ligt er een eind onder.

Als gekeken wordt naar verschillen tussen maatschappelijke groepen, dan zijn religieuze organisaties, landbouworganisaties en organisaties van etnische minderheden de hekkensluiters. Dit zijn dezelfde groepen die ook al in tabel 2 de groepen waren waarvoor parlementsleden het niet erg belangrijk vonden om hun belangen te verdedigen. Ook hier gaat het over een mix van 'oude' en 'nieuwe' groepen. Opmerkelijk is de relatief lage score voor vrouwenorganisaties: zowel in België als in Nederland verklaart slechts ongeveer $18 \%$ van de parlementsleden meer dan één keer per maand contact te hebben met deze organisaties. Dit is voor beide landen significant lager dan de gemiddelde score voor alle landen uit dit onderzoek.

Organisaties waarmee meer parlementsleden vaak contact hebben zijn onder meer vakbonden, werkgeversorganisaties en jongerenorganisaties. Al is voor deze laatste twee soorten organisaties het verschil tussen Belgische en Nederlandse parlementsleden wel erg groot (en telkens ook statistisch significant).

Een tweede manier om belangen van specifieke groepsbelangen aanwezig te stellen in het parlement, is het hebben van volksvertegenwoordigers die afkomstig zijn uit die groep. Door hun gedeelde levenservaring hebben zij meer inzicht in problemen van die groep en geven zij er meer prioriteit aan (Phillips, 1995), zo luidt de redenering.

TABEL 4. Percentage parlementsleden die zeggen dat descriptieve vertegenwoordiging van een bepaalde groep zeer belangrijk is. ${ }^{8}$

\begin{tabular}{|c|c|c|c|c|c|c|c|c|}
\hline & \multicolumn{2}{|c|}{ 'Oude' groepen } & \multicolumn{2}{|c|}{ 'nNeuwe groepen' } & \multicolumn{3}{|c|}{ Andere } & \multirow[b]{2}{*}{ Gemiddelde } \\
\hline & $\begin{array}{c}\text { Sociale } \\
\text { klasse }^{* * *}\end{array}$ & Religie & Leeftijd & Gender** & $\begin{array}{l}\text { Etnische } \\
\text { oorsprong }\end{array}$ & $\begin{array}{l}\text { Taal (of } \\
\text { cultuur) }\end{array}$ & Regio* & \\
\hline België & $6,2 \%$ aaa & $0,6 \%$ & $8,1 \%$ & $18,1 \%$ аa & $5,0 \%$ & $8,7 \%$ & $15,0 \%{ }^{\text {aa }}$ & $10,20 \%$ \\
\hline Nederland & $25,4 \%$ aаa & $3,4 \%$ & $15,5 \%$ & $33,9 \%$ aa & $10,2 \%$ & $3,4 \%$ & $28,8 \%^{\text {aa }}$ & $18,10 \%$ \\
\hline $\begin{array}{l}\text { Alle andere } \\
\text { landen }\end{array}$ & $14,1 \%$ & $2,5 \%$ & $12,6 \%$ & $28,4 \%$ & $7,7 \%$ & $7,4 \%$ & $21,5 \%$ & $14,66 \%$ \\
\hline
\end{tabular}

${ }^{*} \mathrm{p}<0,1 ;{ }^{* *} \mathrm{p}<0,05 ;{ }^{* * *} \mathrm{p}<0,01$ significantie voor globale testen

a $p<0,1$; aa $p<0,05$; aaa $p<0,01$ significant verschillend met België/Nederland 
Algemeen hechten Nederlandse parlementsleden meer belang aan descriptieve vertegenwoordiging dan hun Belgische collega's: het gemiddelde percentage over de onderzochte groepen hier is $10 \%$ voor België, terwijl dit voor Nederland $18 \%$ is. Nederland zit daarmee boven het algemeen gemiddelde, België zit eronder.

Het soort groepen waarvoor de gegarandeerde vertegenwoordiging belangrijk wordt geacht, verschilt ook tussen beide landen. Door Nederlandse parlementsleden wordt veel belang gehecht aan de descriptieve vertegenwoordiging van klasse, gender en - niet geheel verrassend in een kiessysteem met één nationale kieskring - regio's (telkens significant verschillende scores van de Belgische parlementsleden).

In België is de animo voor descriptieve vertegenwoordiging veel lager, ook in vergelijking met andere landen. Gender komt hier naar voor als koploper: 18\% van de Belgische parlementsleden vindt het zeer belangrijk dat de leden van deze groep evenredig tot hun aandeel in de samenleving vertegenwoordigd zijn in het parlement. Deze hoge score voor vrouwen (want over deze groep gaat het concreet) staat in contrast met onze vaststelling op basis van tabel 3, waarbij contacten met vrouwenorganisaties eerder onderaan de rangorde kwamen te staan. Blijkbaar zien parlementsleden vertegenwoordiging van vrouwenbelangen vooral als een proces dat dient waargemaakt te worden door vrouwelijke parlementsleden, eerder dan via contacten met vrouwenorganisaties. Opmerkelijk is wel dat ondanks (of dankzij?) het reeds jarenlange bestaan van gender-quota in België, de steun voor descriptieve vertegenwoordiging van vrouwen significant lager ligt dan in Nederland en dan in de rest van de onderzochte landen.

Voor leeftijd doet zich dan weer het omgekeerde fenomeen voor: een eerder lage score voor descriptieve vertegenwoordiging en een eerder hoge score voor contacten met relevante organisaties. Jonge en/of oudere parlementsleden worden volgens deze resultaten minder nodig of nuttig geacht voor de belangenverdediging van die groep dan contacten met jongeren- en/of ouderenorganisaties.

Een constante doorheen alle tabellen zijn de lage scores voor religie en etnische minderheden. Nagenoeg geen van de parlementsleden vindt het nodig dat mensen uit specifieke religieuze groepen aanwezig zijn in het parlement, en voor allochtonen ligt dit ook duidelijk onder het gemiddelde. Religie, als 'oude' groep, is blijkbaar niet (meer) voldoende relevant in het huidige politieke gebeuren en etnische afkomst, als 'nieuwe' groep, is dat evenzeer (nog) niet. 


\section{Conclusie}

Ongeveer de helft van de parlementsleden in België en zelfs nog iets meer in Nederland hechten belang aan de vertegenwoordiging van maatschappelijke groepen. Groepsvertegenwoordiging is belangrijk voor parlementsleden uit de Lage Landen. In beide landen treffen we een mix aan van oude en nieuwe groepen die parlementsleden menen te moeten vertegenwoordigen. De oude groepen hebben dus niet collectief plaats ingeruimd voor de nieuwe, noch hebben de oude groepen de intrede van nieuwe verhinderd. Sociale klasse is duidelijk nog niet vergeten, vrouwelijke aanwezigheid in het parlement wordt belangrijk geacht, en via contacten met relevante organisaties worden belangen van jongeren en ouderen aan de orde gebracht. Maar niet alle nieuwe en oude groepen zijn relevant voor groepsvertegenwoordiging. Opvallend is dat etnische minderheden maar moeizaam een plaats lijken te verwerven in de groepspolitiek van de Lage Landen en religie als klassieke breuklijn lijkt nog maar weinig parlementsleden warm te maken.

Dit artikel had de ambitie om na te gaan of de gelijklopende verzuilingsgeschiedenis en het feit dat er in beide landen aandacht is voor de gelijke kansen van groepen als vrouwen en etnische minderheden zich zou vertalen naar gelijke patronen in de groepspolitiek in beide landen. We hebben tussen Nederland en België echter meer verschillen gedetecteerd dan verwacht en de gevonden verschillen gaan in tegen de verwachtingen. Nederlandse parlementsleden hechten beduidend meer aandacht aan groepsvertegenwoordiging dan Belgische. Deze bevinding lijkt contradictorisch, aangezien de ontzuiling zich in Nederland vroeger en diepgaander doorzette dan in België. De Nederlandse parlementsleden scoorden echter ook in eerdere onderzoeken (Thomassen \& Esaiasson, 2006) al erg hoog inzake groepsvertegenwoordiging. Het kiessysteem met zijn nationale kieskring, dat minder ruimte laat voor territoriale vertegenwoordiging, werd toen als één van de oorzaken geduid. Niettemin scoren Belgische parlementsleden iets hoger wanneer gepeild wordt naar de wens om afzonderlijke groepen te vertegenwoordigen. Dit doet zich echter zowel bij oude als bij nieuwe groepen voor, dus ook hieruit kunnen we niet concluderen dat de oude groepspolitiek in België nog sterker doorwerkt dan in Nederland. Dat descriptieve vertegenwoordiging van vrouwen in Nederland wenselijker is dan in België is dan weer erg verrassend, gelet op het bestaan van gender-quota in België, net zoals de grote steun in Nederland voor descriptieve vertegenwoordiging in het algemeen.

Dit artikel wijst tot slot interessante wegen aan voor toekomstig onderzoek. Politicologen dienen zich in eerste instantie te buigen over de vraag waarom Nederlandse vertegenwoordigers meer dan gemiddeld gericht zijn op groepspolitiek, wat de stimulansen zijn en met welk resultaat. Ook de vaststelling dat religieuze groepen 
niet langer en etnische minderheden nog niet het onderwerp zijn van groepspolitiek, roept de vraag op of en waarom religie (ook in zekere zin verbonden met etnische minderheden) helemaal op de achtergrond is geraakt in de Lage Landen. Vormt een 'afkeer' van religie de verklaring voor de geringe interesse voor de vertegenwoordiging van etnische minderheden? In scherp contrast met het lot van religie in de hedendaagse politiek in België en Nederland, is de blijvende relevantie van klasse intrigerend. Genereert het neocorporatistische model in beide landen blijvend aandacht voor klasse? En wat zegt dat over de relatieve rol en macht van religieuze organisaties en de Kerk?

De empirische bevindingen in combinatie met het literatuuroverzicht over de evoluties inzake groepsvertegenwoordiging roepen ook de vraag op naar het doel van de groepspolitiek en eventuele verschillen al naargelang van de groep: is het doel socio-economische redistributie, het promoten van bepaalde waarden of het bewerkstelligen van politieke erkenning? Er resten ook nog heel wat vragen inzake de strategie om groepsvertegenwoordiging te realiseren en 'trade-offs' tussen de verschillende strategieën. Voor jongeren en ouderen wordt momenteel vooral ingezet op contacten met relevante organisaties, terwijl voor vrouwen descriptieve vertegenwoordiging de voorkeur geniet. Wat bepaalt de keuze voor de descriptieve of de substantiële strategie? Zijn het groepskenmerken of politieke noden of opportuniteiten en, zo ja, welke dan? En welke strategie is de meest efficiënte?

Tot slot willen we erop wijzen dat we in dit artikel pretendeerden dat groepen los van elkaar staan, wat in de realiteit natuurlijk niet het geval is. De groep vrouwen bijvoorbeeld omvat verschillende klassen, ethnische groepen, leeftijdsgroepen en religies. Dergelijke intersectionele identiteiten genereren allicht eveneens specifieke dynamieken inzake groepspolitiek (Celis, 2012). Het over het algemeen hoge belang dat volksvertegenwoordigers hechten aan groepspolitiek vraagt om verder verklarend onderzoek naar de vertegenwoordiging van maatschappelijke groepen in de Lage Landen en daarbuiten.

\section{Noten}

1. De breuklijn Stad-Platteland was in België noch in Nederland bepalend voor het politieke landschap. De breuklijn Centrum-Periferie was dat zeer zeker voor België onder de vorm van de communautaire breuklijn, maar was niet determinerend in de Nederlandse politiek. Om die redenen beperkt de analyse zich tot groepen die zich op de breuklijnen Arbeid-Kapitaal en Kerk-Staat bevinden en die in beide landen het politieke bedrijf structureerden. 
2. Sociale klasse wordt hier geoperationaliseerd door te kijken naar het beroep van de betrokkenen (werknemer; werkgever; landbouwer en visser). Dit zijn uiteraard zeer brede categoriseringen die geen of weinig ruimte laten voor andere factoren die hierboven aangehaald werden, zoals werkomgeving en jobautonomie. Deze meer fijnmazige opdelingen waren onder meer omwille van de vergelijkbaarheid zeer moeilijk of niet te omschrijven in deze grootschalige internationale enquête.

3. Ook andere groepen hadden geselecteerd kunnen worden zoals holebi's en andersvaliden. Beide staan centraal in de gelijkekansenproblematiek in België en Nederland maar werden om pragmatische redenen niet voor dit internationaal-comparatieve onderzoek geselecteerd. We hopen dat toekomstig onderzoek de vertegenwoordiging van deze groepen wel zal (kunnen) omsluiten.

4. Respondenten die voor elke groep de maximumscore van 7 gaven en tegelijkertijd aangaven in de vraag waarop tabel 1 gebaseerd is dat vertegenwoordiging van groepsbelangen voor hen niet belangrijk was, zijn parlementsleden die voor iedereen willen opkomen en dus geen groepsvertegenwoordiger zijn. Ze zijn uit de analyse verwijderd.

5. Per sociale groep werden twee keer twee soorten statistische testen uitgevoerd. Voor de gemiddelde score werd een globale ANOVA-analyse uitgevoerd om na te gaan of de verschillende groepen van elkaar verschillen, en afhankelijk van de gelijkheid van de varianties een Tukey-test of een Tamhane-test om na te gaan of er verschillen zijn tussen Nederlandse en Belgische parlementsleden. Voor \% (cath 6-7) werd een globale

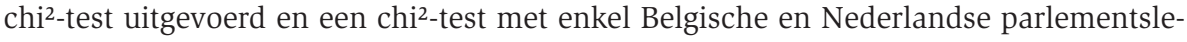
den.

6. Percentage respondenten dat een score van 6 of 7 toekent aan het belang van het opkomen van de belangen voor deze groepen. Omdat voor sommige groepen de percentages uit de hogere categorieën zeer hoog zijn, wordt ervoor geopteerd om een meer strikte afbakening te gebruiken in vergelijking met tabel 1, namelijk enkel zij die een score van 6 of 7 gaven.

7. Er werd per groep een chi²-test uitgevoerd om globale verschillen na te gaan en een chi $^{2}$-test op alle Belgische en Nederlandse parlementsleden om na te gaan of de verschillen tussen deze beide landen statistisch significant zijn.

8. Er werd per groep een chi $^{2}$-test uitgevoerd om globale verschillen na te gaan en een chi $^{2}$-test op alle Belgische en Nederlandse parlementsleden om na te gaan of de verschillen tussen deze beide landen statistisch significant zijn. 


\section{Bibliografie}

Bartolini, S. (2005). La formation des clivages, Revue internationale de politique comparé, 12 (1), 9-34.

Bartolini, S. \& Mair, P. (1990). Identity, Competition, and Electoral Availability: The Stabilization of European Electorates, 1885-1985. New York: Cambridge University Press.

Bird, K. (2004). Obstacles to Ethnic Minority Representation in Local Government in Canada. In: C. Andrew (Ed.), Our Diverse Cities (pp. 182-186). Ottowa: Metropolis and the Federation of Canadian Municipalities.

Blumler, J.G. \& Kavanagh, D. (1999). The Third Age of Political Communication: Influences and Features, Political Communication, 16 (3), 209-30.

Bornschier, S. (2010). The New Cultural Divide and the Two-Dimensional Political Space in Western Europe, West European Politics, 33 (3), 419-44.

Bovens, M. \& Wille, A.C. (2011). Diplomademocratie: Over de spanning tussen meritocratie en democratie. Amsterdam: Uitgeverij Bert Bakker.

Celis, K. (2012). Gender \# Ethnicity. Parties Regulating Descriptive Representation at the Intersection of Gender and Ethnicity. Paper gepresenteerd in de workshop 'Gender \& Regulation: Moving Beyond Official Quotas', 28-29 June 2012, Leiden.

Celis, K., Eelbode, F, \& Wauters, B. (2011). Ethnic Minorities in Local Political Parties. A Case study of Three Belgian Cities (Antwerp, Ghent and Leuven). Paper gepresenteerd op de ECPR General Conference, 25-27 August 2011, Reykjavik.

Celis, K., Outshoorn, J., Meier P. \& Motmans J. (2012, te verschijnen). Institutionalizing Intersectionality in the Low Countries: Belgium and The Netherlands. In J. Squires, H. Skjeie \& A. Krizsan (Eds.), Institutionalizing Intersectionality: The Changing Nature of European Equality Regimes. Basingstoke: Palgrave Mcmillan.

Celis, K. \& Wauters, B. (2010). Vastgepinde vlinders. Vrouwelijke, allochtone en arbeiders-parlementsleden ten opzichte van parlementaire normen en de rol van groepsvertegenwoordiger. In K. Celis, P. Meier \& B. Wauters (Eds.), Gezien, gehoord, vertegenwoordigd? Diversiteit in de Belgische politiek (pp. 225-244). Gent: Academia Press.

Clark, T.N. \& Lipset, S.M. (1991) Are Social Classes Dying?, International Sociology, 6 (4), 397-410.

Cowley, Ph. \& Childs, S. (2003). Too Spineless to Rebel? New Labour's Women MPs, British Journal of Political Science, 33 (3), 345-365.

Dalton, R., Flanagan, S.C. \& Beck, P.A. (Eds.). (1984). Electoral Changes in Advanced Industrial Democracies. Realignment or Dealignment? Princeton, NJ: Princeton University Press.

Deschouwer, K. \& Lucardie, P. (2003). Partijen en partijsystemen in Nederland en Vlaanderen, Sociologische Gids, 50 (2), 131-155.

Dolezal, M. (2010). Exploring the Stabilization of a Political Force: The Social and Attitudinal Basis of Green Parties in the Age of Globalization, West European Politics, 33 (3), 534-52. 
Enyedi, Z. (2008). The Social and Attitudinal Basis of Political Parties: Cleavage Politics Revisited, European Review, 16 (3), 287-304.

Enyedi, Z. \& Deegan-Krause, K. (Eds.) (2010). The Structure of Political Competition in Western Europe, London: Routledge.

Evans, G. (Ed.). (1999). The End of Class Politics? Oxford: Oxford University Press.

Flanagan, S.C. (1987). Value Change in Industrial Societies, American Political Science Review, 81 (4), 1303-19.

Franklin, M. N., Mackie, T. \& Valen, H. (Eds.). (1992). Electoral Change. Responses to Evolving Social and Attitudinal Structures in Western Countries. Cambridge: Cambridge University Press.

Fraser, N. (1997). Justice Interruptus. Critical Reflexions on the 'Postsocialist' Condition. London-New York: Routledge.

Huyse, L. (1970). Passiviteit, pacificatie en verzuiling in de Belgische politiek. Een sociologische studie. Antwerpen: Standaard Wetenschappelijke Uitgeverij.

Inglehart, R. (1977). The Silent Revolution: Changing Values and Political Styles among Western Publics. Princeton, NJ: Princeton University Press.

Inglehart, R. \& Baker, W.E. (2000). Modernization, Cultural Change, and the Persistence of Traditional Values, American Sociological Review, 65 (1), 19-51.

Inglehart, R. \& Norris, P. (2000). The Developmental Theory of the Gender Gap: Women's and Men's Voting Behavior in Global Perspective, International Political Science Review, 21 (4), 441-463

Irwin, G. \& Van Holsteyn, J. (2002). De kloof tussen burger en bestuur. In J. Van Holsteyn \& C. Mudde (Eds.), Democratie in verval? (pp. 33-50). Amsterdam: Boom.

Katz, R. \& Mair, P. (1995). Changing Models of Party Organization and Party Democracy: The Emergence of the Cartel Party, Party Politics, 1 (1), 5-28.

Kirchheimer, O. (1966). The Transformation of West European Party Systems. In J. Palombara and M. Weiner (Eds), Political Parties and Political Development (pp. 177200). Princeton: Princeton University Press.

Kitschelt, H. (1994). The Transformation of European Social Democracy. Cambridge: Cambridge University Press.

Knutsen, O. \& Scarbrough, E. (1995). Cleavage Politics. In: J. W. Van Deth \& E. Scarbrough (Eds.), The Impact of Values (pp. 492-523). Oxford: Oxford University Press.

Kriesi, H. (2010). Restructuration of Partisan Politics and the Emergence of a New Cleavage Based on Values, West European Politics, 33 (3), 673-685.

Krook, M.L. (2009). Quotas for Women in Politics: Gender and Candidate Selection Reform Worldwide. New York: Oxford University Press.

Lijphart, A. (1968). The Politics of Accommodation: Pluralism and Democracy in the Netherlands. Berkeley: University of California Press.

Lipset, S.M. \& Rokkan, S. (1967). Party Systems and Voter Alignments: Cross-national Perspectives. Toronto: The Free Press. 
Meier, P. (2000). The Evidence of Being Present: Guarantees of Representation and the Example of the Belgian Case, Acta Politica, 35 (1), 64-85.

Oesch, D. (2008). The Changing Shape of Class Voting: An Individual-Level Analysis of Party Support in Britain, Germany and Switzerland, European Societies, 10 (3), 329-55.

Outshoorn, J. \& Oldersma, J. (2007). Dutch Decay: The Dismantling of the Women's Policy Network in the Netherlands. In J. Outshoorn \& J. Kantola (Eds.), Changing State Feminism (pp. 182-201). Basingstoke: Palgrave Mcmillan.

Przeworski, A. \& Sprague, J. (1988). Paper Stones: A History of Electoral Socialism. Chicago: University of Chicago Press.

Phillips, A. (1995). The Politics of Presence. Oxford: Clarendon Press.

Phillips, A. (1999) Which Equalities Mtter? Cambridge: Polity Press.

Quintelier, E. \& Hooghe, M. (2010). Verenigingen, lidmaatschap en kiesgedrag: is de verzuiling nu helemaal voorbij? In: K. Deschouwer, P. Delwit, M. Hooghe \& S. Walgrave (Eds.), De stemmen van het volk. Een analyse van het kiesgedrag in Vlaanderen en Wallonië op 7 juni 2009 (pp. 99-121). Brussel: VUBPress.

Stubager, R. (2009). Education-based Group Identity and Consciousness in the Authoritarian-Libertarian Value Conflict, European Journal of Political Research, 48 (2), 204-233.

Thomassen, J. \& Esaiasson, P. (2006). Role Orientations of Members of Parliament, Acta Politica, 41 (3), 217-231.

Tóka, G. \& Gosselin, T. (2010). Persistent Political Divides, Electoral Volatility and Citizen Involvement: The Freezing Hypothesis in the 2004 European Election, West European Politics, 33 (3), 608-633.

Van der Brug, W. (2010). Structural and Ideological Voting in Age Cohorts, West European Politics, 33 (3), 586-607.

Van der Kolk, H. (2000a). Aarzelende, zwevende en wisselende kiezers. In J. Thomassen, K. Aarts \& H. Van der Kolk (Eds.), Politieke verandering in Nederland 19711998. Kiezers en de smalle marges van de politiek (pp. 93-120). Den Haag: Sdu.

Van der Kolk, H. (2000b). Het afnemend belang van godsdienst en klasse. In J. Thomassen, K. Aarts \& H. Van der Kolk (Eds.), Politieke verandering in Nederland 19711998. Kiezers en de smalle marges van de politiek (pp. 121-152). Den Haag: Sdu.

Van der Waal, J., Achterberg, P. \& Houtman, D. (2007). Class Is Not Dead - It Has Been Buried Alive: Class Voting and Cultural Voting in Postwar Western Societies (19561990), Politics \& Society, 35 (3), 403-426.

Wauters, B. (2012). Blue Collars Striking the Red Flag. Formal and Descriptive Representation of the Working Class in the Belgian House of Representatives 1946-2007, Labor History, 53 (2), 225-243. 
VERTEGENWOORDIGING VAN OUDE EN NIEUWE BREUKLIJNEN IN DE LAGE LANDEN

\section{Appendix: Gebruikte gewichten per parlementaire} fractie

\begin{tabular}{|c|c|c|}
\hline & $\mathrm{N}$ observaties & $\begin{array}{l}\text { Gewicht gebuikt voor parlemen- } \\
\text { taire sterkte }\end{array}$ \\
\hline CD\&V (Brussel) & 2 & ,44569 \\
\hline CD\&V (federaal) & 12 & ,89444 \\
\hline CD\&V-N-VA (Vlaanderen) & 8 & 1,26278 \\
\hline N-VA (federaal) & 3 & 1,08889 \\
\hline CDH (Brussel) & 3 & 1,08946 \\
\hline $\mathrm{CDH}$ (federaal) & 6 & ,77778 \\
\hline CDH (Wallonië) & 3 & 1,38658 \\
\hline CSP (Duitstalig) & 2 & 1,18850 \\
\hline ECOLO (Brussel) & 4 & ,51997 \\
\hline ECOLO (Duitstalig) & 1 & ,59425 \\
\hline Groen-ECOLO (federaal) & 6 & ,93333 \\
\hline Groen (Brussel) & 1 & 29713 \\
\hline Groen (Vlaanderen) & 1 & 1,78275 \\
\hline OpenVLD (Brussel) & 1 & 1,18850 \\
\hline OpenVLD (federaal) & 6 & 1,40000 \\
\hline OpenVLD (Vlaanderen) & 9 &, 82535 \\
\hline MR (Brussel) & 6 & 1,18850 \\
\hline MR (federaal) & 9 & 1,19259 \\
\hline MR (Wallonië) & 9 & ,66028 \\
\hline PFF (Duitstalig) & 3 & ,49521 \\
\hline LDD (federaal) & 1 & 2,33333 \\
\hline SP.A-Spirit (Brussel) & 2 & ,44569 \\
\hline SP.A-Spirit (Vlaanderen) & 13 & ,57139 \\
\hline SP.A (federaal) & 9 & ,72593 \\
\hline PS (Brussel) & 5 & 1,54505 \\
\hline PS (federaal) & 10 & ,93333 \\
\hline PS (Wallonië) & 7 & 1,44318 \\
\hline SP (Duitstalig) & 1 & 1,48562 \\
\hline VB (Brussel) & 2 & 74281 \\
\hline VB (federaal) & 7 & 1,13333 \\
\hline VB (Vlaanderen) & 4 & 2,15415 \\
\hline FN (Brussel) & 1 & 1,18850 \\
\hline FN (federaal) & 1 & ,46667 \\
\hline FN (Wallonië) & 1 & 1,18850 \\
\hline Vivant (Duitstalig) & 1 & ,59425 \\
\hline PJU-PDB (Duitstalig) & 3 & 29713 \\
\hline CDA & 21 & ,84603 \\
\hline CU & 3 & ,86667 \\
\hline Groen Links & 1 & 3,03333 \\
\hline PvdA & 19 & ,75263 \\
\hline PvdD & 2 & ,43333 \\
\hline SP & 8 & 1,35417 \\
\hline WD & 11 & ,82727 \\
\hline
\end{tabular}

